\title{
ANALISIS DAN PERANCANGAN APLIKASI AUTOMAIL
}

\author{
Indrajani $^{1}$ \\ ${ }^{1}$ Jurusan Sistem Informasi, Fakultas Ilmu Komputer, Universitas Bina Nusantara, \\ Jl. K.H. Syahdan No. 9, Kemanggisan/Palmerah, Jakarta Barat 11480 \\ indrajani@yahoo.com
}

\begin{abstract}
Article analysis business process of a running report delivery and designes an automatied report delivery to the $A B C$ company partner by noticing the safety of data transfered. The used methods are literature, interview, survey, analysis, and design method. The result is indicates that there is email automation by automail application. The conclusion is the automail analysis and design was cover verification process, text file encoding, and report delivery by encryption-description process as form of data safety.
\end{abstract}

Keywords: system analysis, design analysis, automail application

\begin{abstract}
ABSTRAK
Artikel menganalisis proses bisnis pengiriman laporan yang berjalan dan merancang suatu otomasi pengiriman laporan pada company partner PT ABC dengan memperhatikan keamananan data yang dikirim. Metode penelitian yang digunakan, adalah studi pustaka, wawancara, survei, metode analisis, dan metode perancangan. Hasil yang dicapai adalah ketersediaan sarana otomasi email melalui aplikasi automail. Simpulan yang didapat adalah analisis dan perancangan automail ini mencakup proses verikasi, pemecahan text file, dan pengiriman laporan yang telah melalui enkripsi-deskripsi sebagai bentuk keamanan data.
\end{abstract}

Kata kunci: analisis sistem, perancangan sistem, aplikasi automail

\section{PENDAHULUAN}

Dengan semakin meningkatnya jumlah transaksi yang terjadi pada sejumlah company partner setiap harinya, perlu adanya pengiriman laporan transaksi yang dilakukan setiap harinya secara tepat waktu. Adapun cakupan wilayah kerja pengiriman laporan transaksi ini adalah antara kantor pusat PT ABC dengan company partner, seperti Standard Chartered Bank, The Hongkong And Shanghai Bank, PT Anz Panin Bank, American Express Bank LTD, PT Indointernet, PT Thames Pam Jaya, dan sebagainya. Saat ini, pengiriman laporan transaksi dilakukan dengan cara membuka sebuah laporan yang berisi seluruh company partner yang berasal dari mainframe kemudian memecahmecah laporan tersebut berdasarkan kode company partner dengan cara men-copy paste pada file txt yang baru. Akibatnya banyak terjadi human error, baik yang dilakukan dengan tidak sengaja ataupun sengaja, dan laporan tersebut pada saat proses copy paste ada yang tidak ter-copy, lalu ada yang sengaja mengubah-ubah nomor rekening dan jumlah yang ditransfer, dan sebagainya.

Setelah itu, laporan yang telah terpecahpecah berdasarkan kode company partner tersebut kemudian di zip dengan password dan dikirim pada company partner bersangkutan via email kemudian company partner akan membuka laporan yang dikirim dan akan dikonsolidasikan dengan sistem informasi pada perusahaan mereka. Oleh karena itu, laporan transaksi yang dikirim tersebut harus valid, sah, akurat, dan data yang ada di dalamnya tidak boleh mengalami perubahan dengan sengaja atau tidak sengaja. Automail adalah singkatan auto email, yaitu otomasi proses verifikasi data, pemecahan laporan, dan pengiriman data dengan enkripsi untuk mengurangi human error tentunya. Berangkat dari permasalahan dan pengertian tersebut maka dilakukanlah analisis dan perancangan Automail.

Analisis dan perancangan automail ini hanya terbatas pada proses berikut. Pertama, proses verifikasi data, yaitu proses terjadi perhitungan digit secara otomatis setiap baris detail laporan melalui 
rumus yang telah disepakati oleh programmer mainframe dan dibandingkan dengan jumlah yang tertera pada akhir laporan. Kedua, proses pemecahan data, yaitu proses laporan yang berisi seluruh laporan company partner kemudian dipecah-pecah menjadi file txt dengan nama berdasarkan kode company partner. Ketiga, proses pengiriman data dengan enkripsi dan deskripsi, yaitu proses laporan yang berupa file txt diubah menjadi file pgp menggunakan free software PGP.

Tujuan penelitian adalah menganalisis sistem pengiriman laporan yang berjalan dan merancang aplikasi Automail. Manfaat yang diperoleh penelitian adalah kemudahan dalam melakukan proses pengiriman laporan, yaitu secara otomatis; Mempercepat proses pengiriman laporan; Menghilangkan risiko penggantian data pada laporan.

Metode yang digunakan dalam penelitian ini adalah Metode Pengumpulan Data, yaitu dengan studi pustaka, survei lapangan, wawancara, dan kuesioner; Metode Analisis; Metode Perancangan Sistem dengan metode Unified Modelling Language $(U M L)$ menggunaakan pendekatan Object Oriented Analysis \& Design (OOAD) yang di dalamnya mencakup Class Diagram, State Chart, Use Case Diagram, Sequence Diagram, Component Diagram, Deployment Diagram, dan pembuatan rancangan layar.

\section{PEMBAHASAN}

Sistem adalah kumpulan komponen peralatan model requirements, function, dan interface (Mathiassen and Munk-Madsen, 2000). Sistem Informasi merupakan kombinasi teratur apapun dari sumber daya manusia, hardware, software, data, dan jaringan (O’Brien, 2004). Daur hidup suatu sistem, meliputi Investigasi; Analisis; Desain; Implementasi; Pemeliharaan.

\section{Unified Model Diagram}

Unified Model Diagram (UML) adalah bahasa standar untuk menulis cetakan biru software. UML digunakan untuk memvisualisasi, menspesifikasi, membangun, dan mendokumentasikan hasil dari sebuah sistem intensif software. Use Case menunjukkan hubungan interaksi dari actors dan use cases di dalam suatu sistem (Mathiassen and Munk-Madsen, 2000) yang bertujuan untuk menentukan bagaimana actors berinteraksi dengan sebuah sistem. Statechart
Diagram menggambarkan state (keadaan) yang dialami semua objek dalam suatu class yang specific serta transisi (event) yang memicu terjadinya suatu state. Class Diagram menggambarkan kumpulan class yang ada serta hubungan diantara class tersebut. Class mempunyai attributes dan operations yang berbeda-beda.

\section{Basis Data}

Database adalah kumpulan data komputer terintegrasi, terorganisasi, dan disimpan dalam sebuah fasilitas yang mudah digunakan. Alat penyimpanan akses langsung harus digunakan oleh semua data perusahaan dan dapat diintegrasikan (Connolly, 2002). Database adalah penggunaan bersama dari data yang terhubung secara logis dan deskripsi dari data yang dirancang untuk keperluan informasi suatu perusahaan. Dua tujuan utama konsep database adalah untuk memperkecil pengulangan data dan mencapai independensi data. Pengulangan data (data redudansi) adalah duplikasi dari data, yaitu data yang sama yang disimpan dalam bermacam-macam file. Independensi data adalah kemampuan untuk membuat perubahan dalam struktur data tanpa membuat perubahan untuk program yang memproses data. Independensi data dilakukan melalui penempatan spesifikasi data dalam tabel dan kamus yang terpisah secara khusus dari program. Program tersebut menunjukkan tabel dalam pemesanan untuk mengakses data. Perubahan struktur data hanya dilakukan sekali di dalam tabel.

\section{Interaksi Manusia dan Komputer}

IMK (Interaksi Manusia Komputer) adalah suatu studi mengenai bagaimana manusia berinteraksi dengan komputer dan sampai sejauh mana komputer dikembangkan untuk interaksi yang berhasil dengan manusia. Satu faktor penting IMK adalah user yang berbeda akan membentuk konsepsi atau model mental yang berbeda mengenai cara mereka berinteraksi, belajar, dan menyimpan pengetahuan dan keahlian (model kognitif yang berbeda untuk orang dengan "left-brained" dan "right-brained"). Pada akhirnya, preferensi user akan berubah setelah mereka secara gradual menguasai interface baru (Shneiderman, 1998).

\section{Enkripsi}

Menurut Sarita Singh (2007), "One of the common security controls is encryption. Encryptions refers to process of disguising a 
message in such a way to hide its substances". The encrytion transformation depends on the keystreams being generated.The keystreams could be generated at random, or by an algorithm which generates the keystream from an initial small secret (called a seed) or from a seed and previous chipertext bits. Such an algorithm is called a keystreams generator." Salah satu free software yang digunakan untuk enkripsi adalah Pretty Good Sofware Present (PGP). Dalam penggunaannya, PGP menggunakan file pubring.pgp dan secring.pgp, serta randseed.bin untuk menyimpan key. Fungsi PGP, antara lain Encrypting a Message,Encrypting a Message to Multiple Recipients,Decrypting and Checking Signatures,Managing Keys,Adding a Key to Your Key Ring, dan Removing a Key or User ID from Your Key Ring.

\section{Pembahasan}

Prosedur sistem yang berjalan, yaitu Operator mendownload data yang berisi sejumlah laporan dari connect direct; Operator menyimpan data tersebut pada direktori di PC; Operator membuka dengan program text editor dan memecah-mecahkan data tersebut sesuai dengan kode company partner dan menyimpannya untuk dienkripsi; Proses enkripsi menggunakan program PGP; Operator mengirimkan file yang berisi laporan dan terenkripsi tersebut pada company partner; Proses pengiriman file menggunakan program microsoft outlook.

Identifikasi masalah dalam penelitian sebagai berikut. Pertama, terdapat fraud pada proses pengiriman laporan, yaitu pada laporan tersebut sebelum dikirim pada company partner diubah isinya demi kepentingan orang-orang tertentu yang pasti sangat merugikan perusahaan. Kedua, banyak kesalahan yang terjadi dalam proses pemecahan data karena dilakukan secara manual. Misalnya, penamaan kode company partner dan laporan ada yang terbawa company partner lain. Ketiga, faktor kesalahan manusia sering terjadi, misalnya setelah memecah-mecahkan data lupa mengenkripsi dan lupa mengirimkan pada company partner.

Usulan pemecahan masalah sebagai berikut. Pertama, membuat perancangan automail yang berisi proses pemecahan data, verifikasi data, enkripsi data, dan pengirimana data pada company partner. Kedua, dengan perancangan automail, aktivitas manusia dikurangi semaksimal mungkin sehingga proses enkripsi dan pengiriman akan termonitoring setiap hari. Ketiga, dengan adanya aplikasi automail,

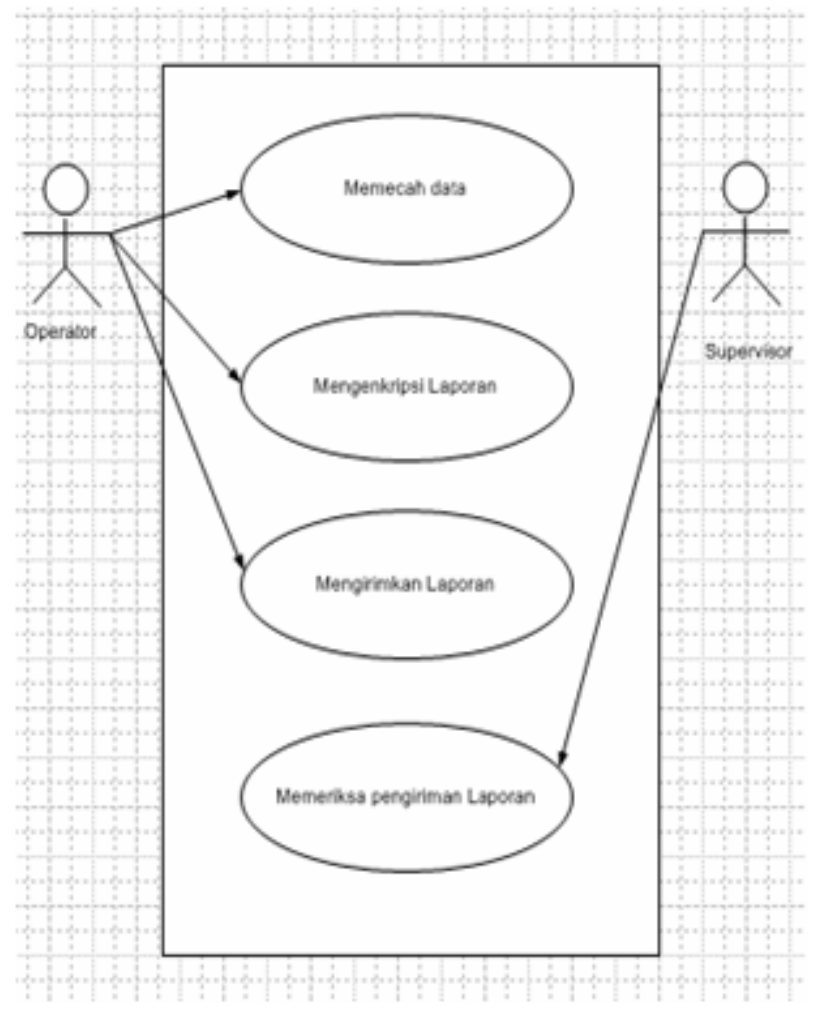

Gambar 1 Use Case Sistem yang Sedang Berjalan 
yaitu terdapat proses verifikasi data otomatis di dalamnya, membuat orang tidak dapat mengubah isi laporan tersebut.

Prosedur baru yang diusulkan, yaitu Operator men-download data yang berisi sejumlah laporan dari connect direct; Operator menyimpan data tersebut pada direktori di PC; Operator menjalankan program automail yang berfungsi untuk memecah data tersebut sesuai dengan kode company partner dan menyimpannya untuk dienkripsi serta mengirimkan file yang berisi laporan pada company partner dan semua proses tersebut dijalankan secara otomatis; Operator meregister data company partner; Operator akan mengirim ulang laporan yang gagal dan bermasalah dengan override supervisor; Operator mencetak laporan aktivitas jika diperlukan; Supervisor memeriksa laporan yang gagal dan bermasalah dalam proses pemecahan hingga pengiriman; Admin membuat user baru dengan level operator atau supervisor.

\section{Class Diagram}

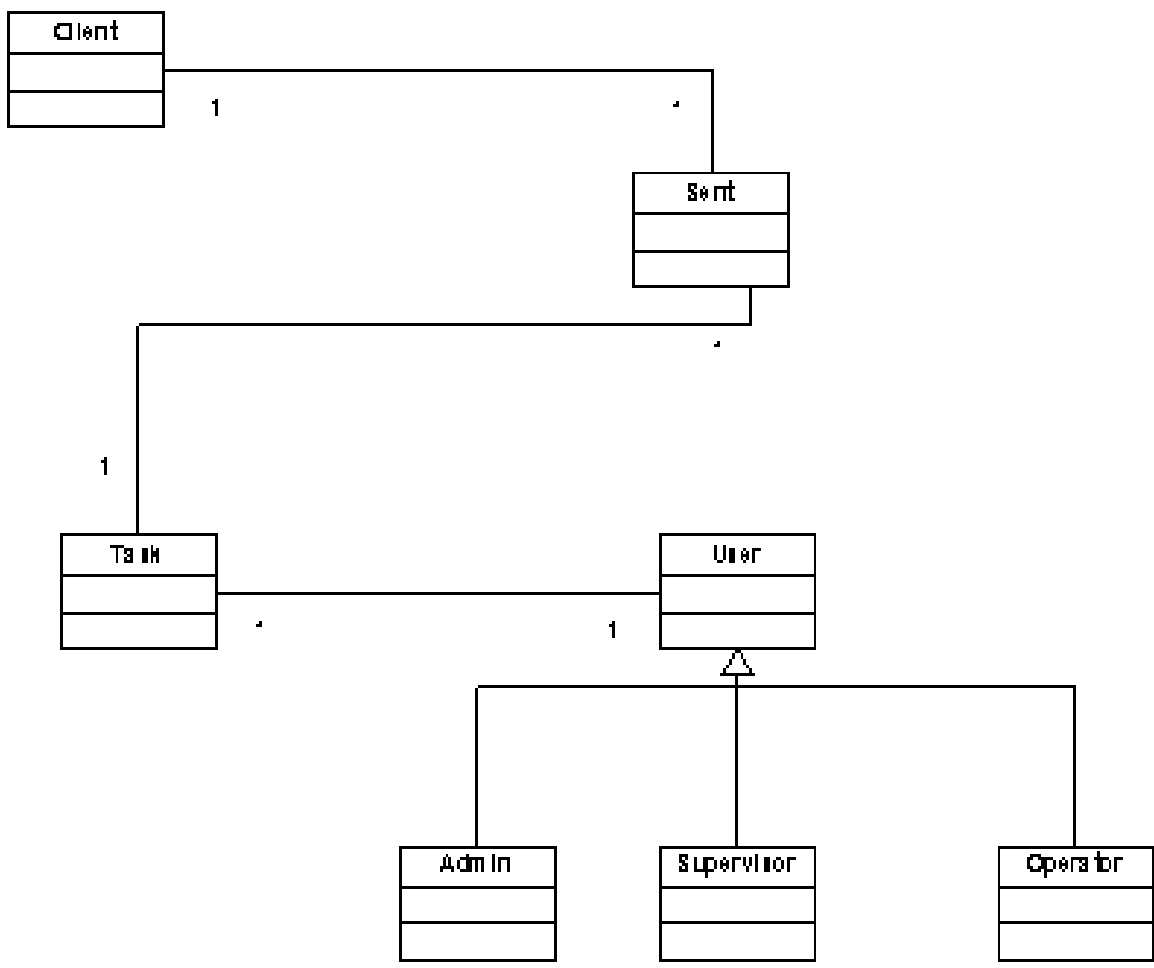

Gambar 2 Class Diagram 


\section{State Chart}

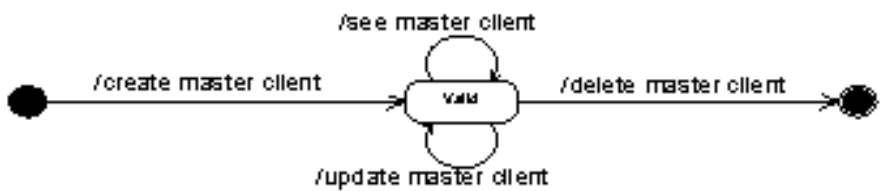

Gambar 3 State Chart Client

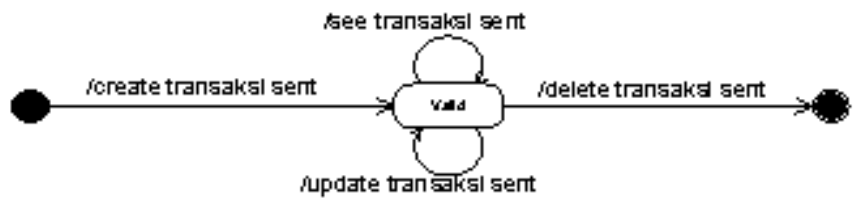

Gambar 4 State Chart Sent

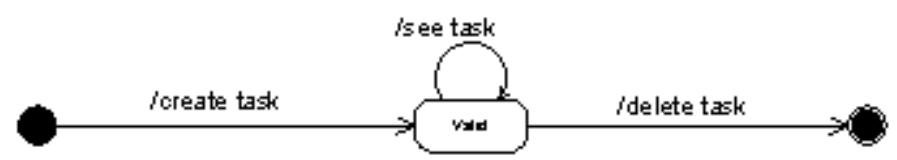

Gambar 5 State Chart Task

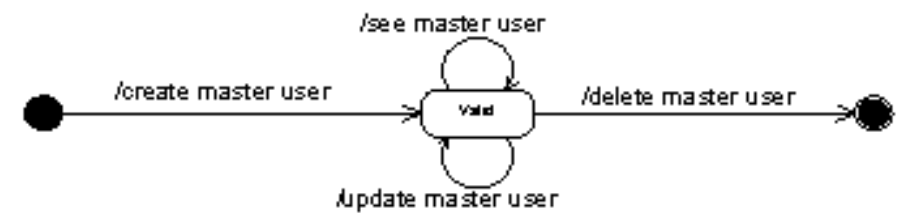

Gambar 6 State Chart User

\section{Use Case}

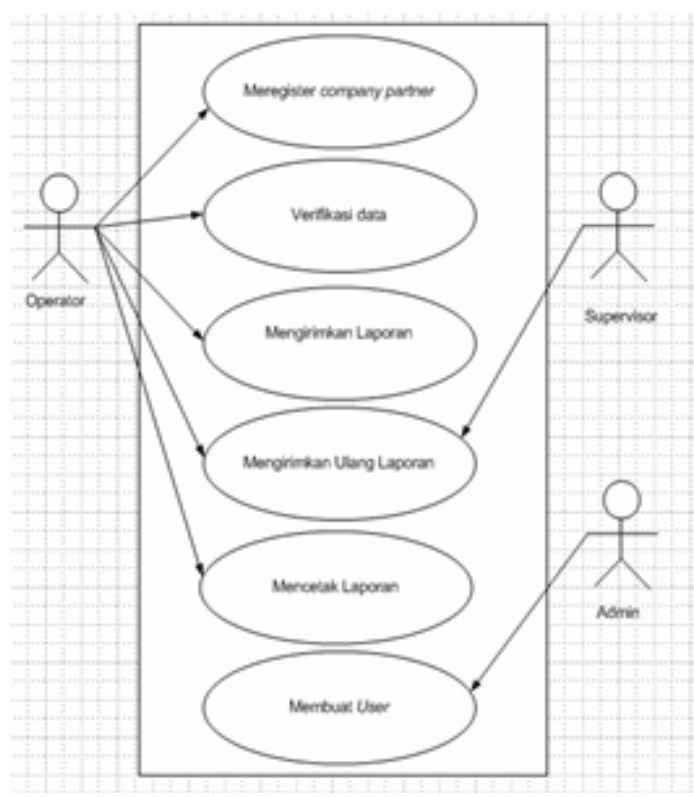

Gambar 7 Use Case Sistem yang Diusulkan 


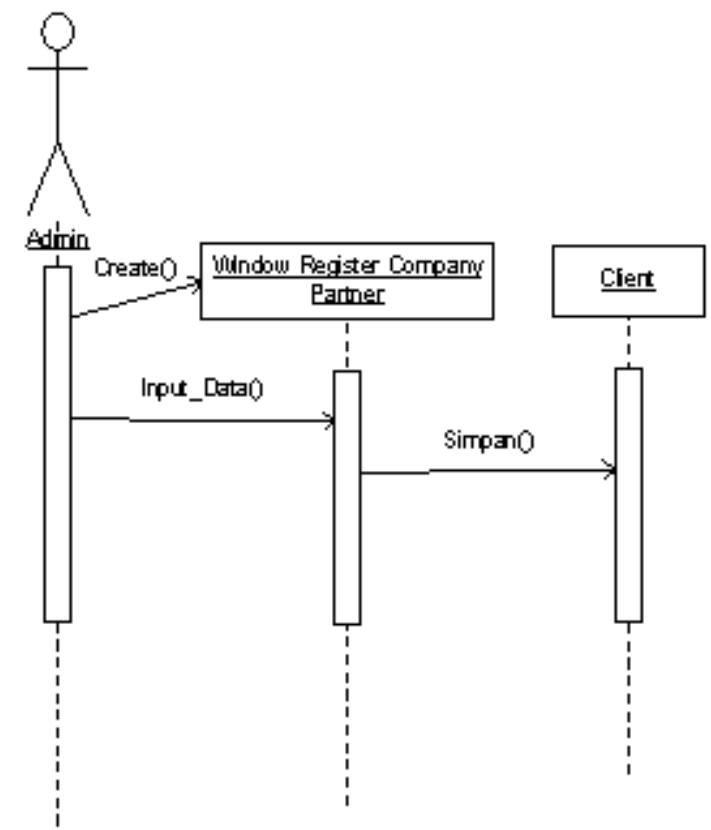

Gambar 8 Sequence Register Company Partner

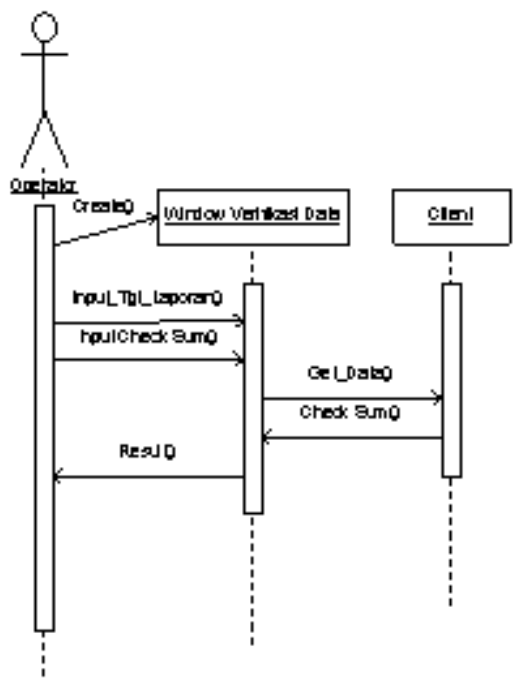

Gambar 9 Sequence Verifikasi data 


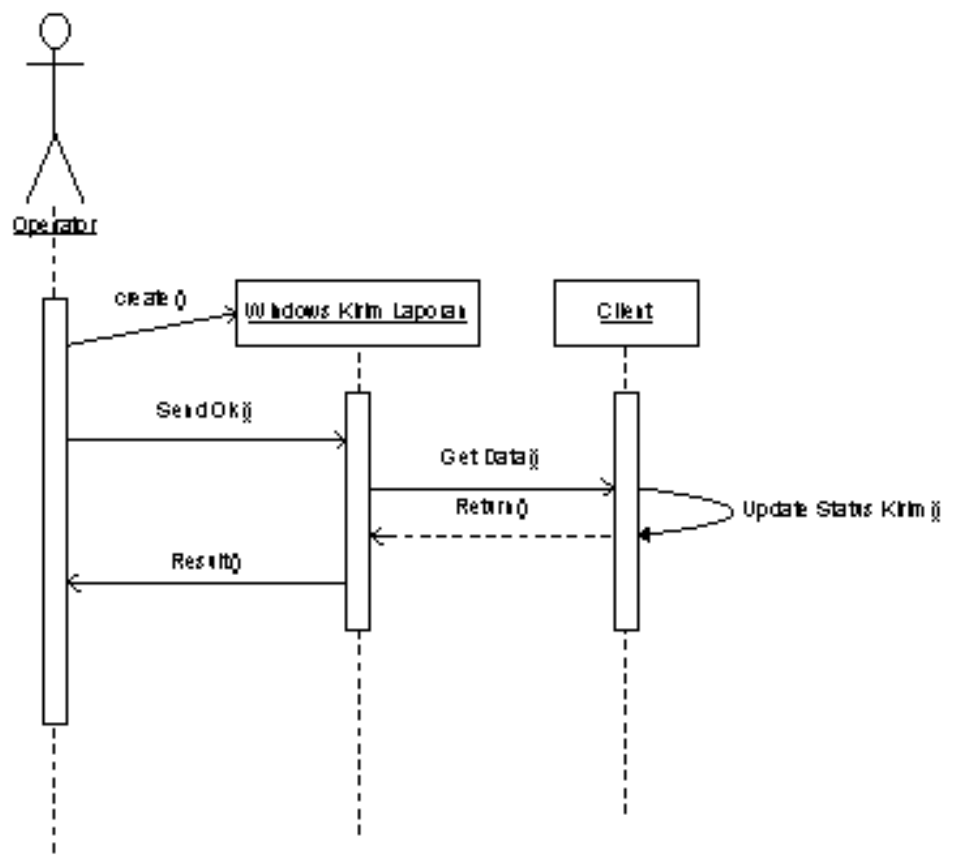

Gambar 10 Sequence KirimLaporan

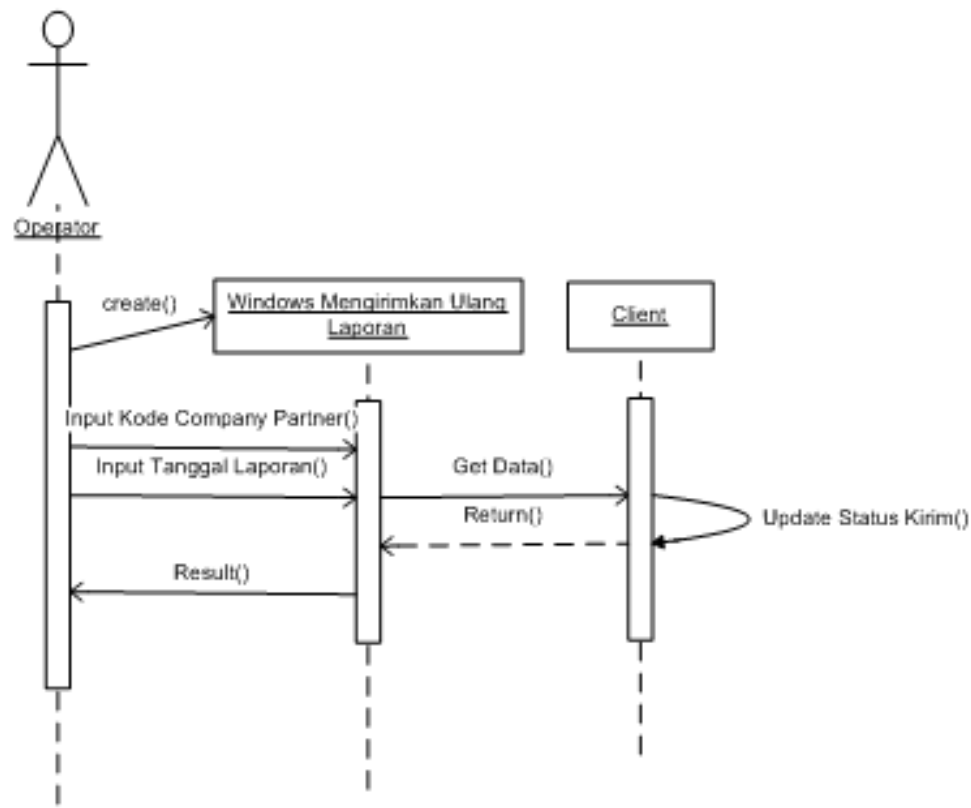

Gambar 11 Sequence Mengirimkan Ulang Laporan 


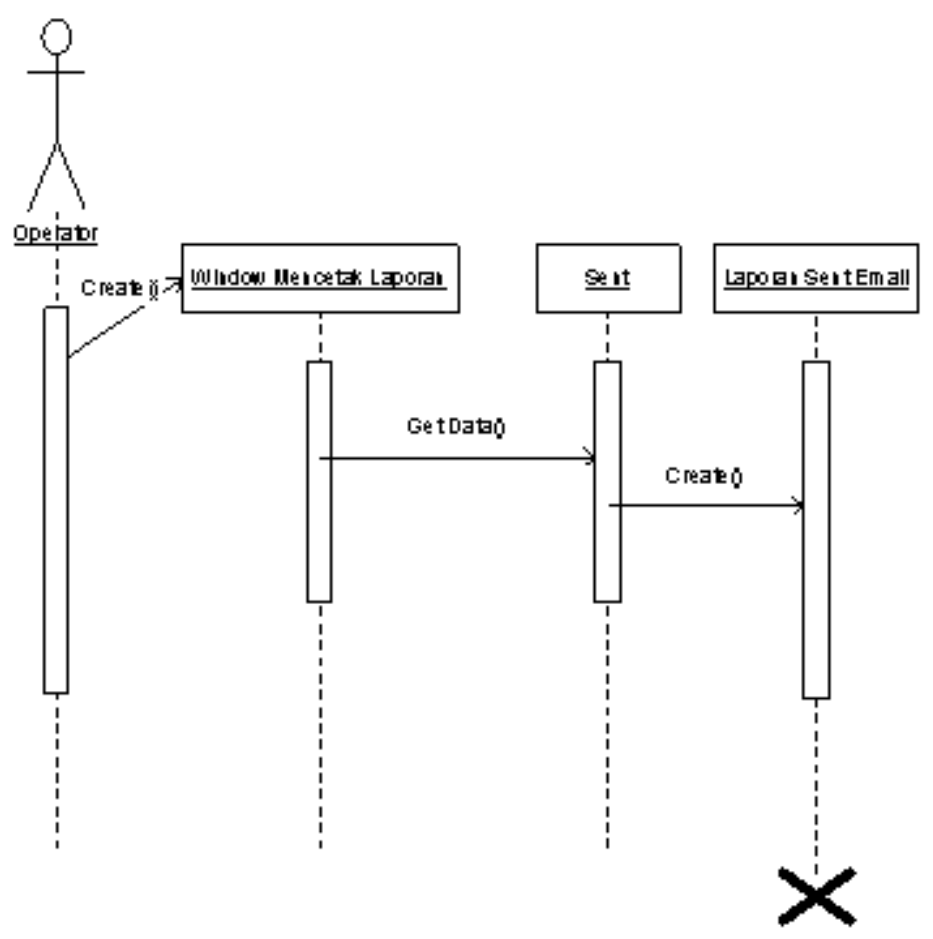

Gambar 12 Sequence Mencetak Laporan

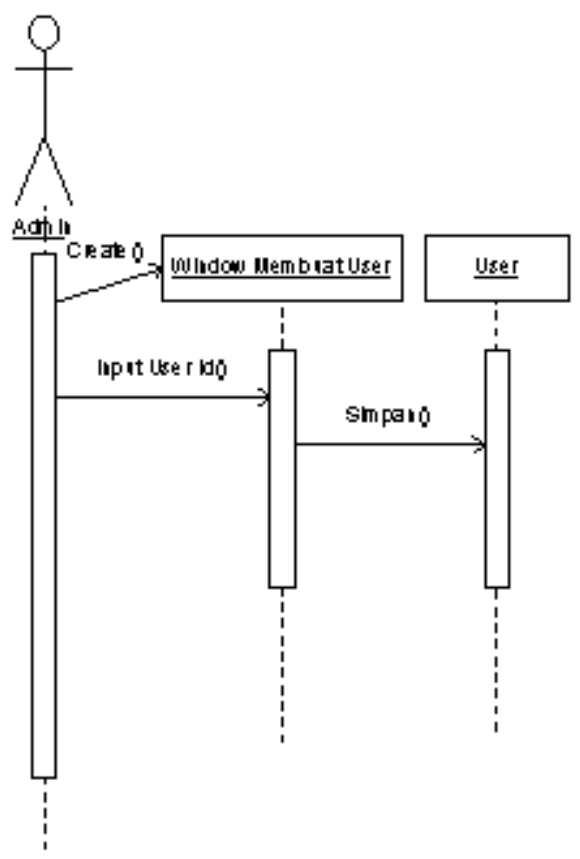

Gambar 13 Sequence Membuat User 


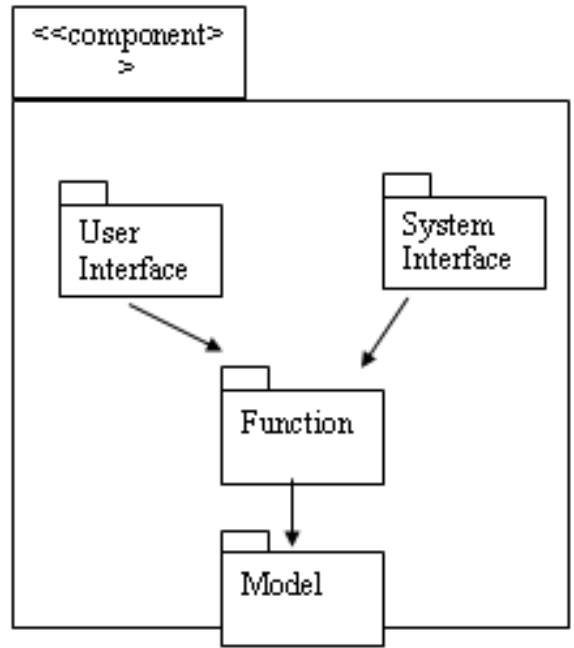

Gambar 14 Component Diagram

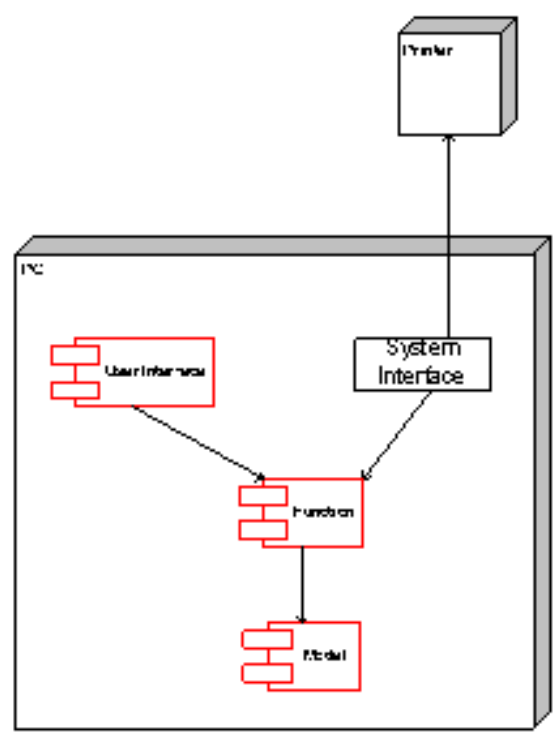

Gambar 15 Deployment Diagram

\section{Perancangan Menu}

1. File

\subsection{Open}

1.1.1. Address Book

1.1.2. Properties

1.1.3. User Profile

1.2.Change Password

1.3.Sign Off

2. Run

2.1. Report Verification

2.2. Send Email

2.3.Purge File
3. View

3.1. Address Book

3.2. Verification \& Send Result

3.3.User Activities

4. Print

4.1. Address Book

4.2. User Activitas

4.3. Sent Email

5. Help

5.1.Help Topics 


\section{Perancangan Basis Data}

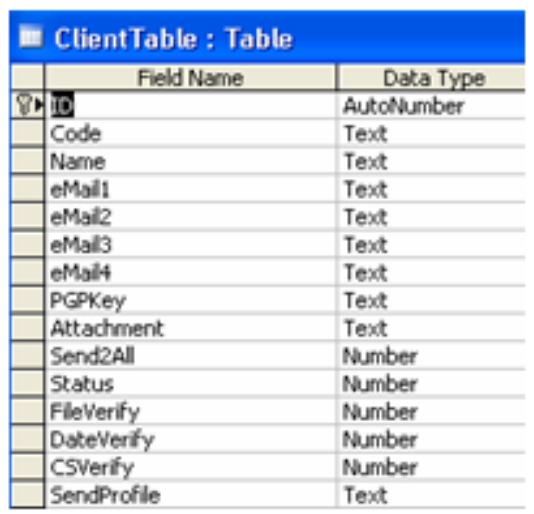

\begin{tabular}{|c|c|}
\hline \multicolumn{2}{|l|}{ Ei SentTable : Table } \\
\hline Field Name & Data Type \\
\hline (B) ID & AutoNumber \\
\hline SentCode & Text \\
\hline SentTo & Text \\
\hline SentDate & Text \\
\hline SentTime & Text \\
\hline SentBy & Text \\
\hline Sentstatus & Number \\
\hline
\end{tabular}

Gambar 16 Tabel Client Table dan Tabel Sent Table

\begin{tabular}{|c|c|}
\hline \multicolumn{2}{|c|}{ E TasksTable : Table } \\
\hline Field Name & Data Type \\
\hline BD 10 & AutoNumber \\
\hline Userid & Text \\
\hline TaskDate & Text \\
\hline TaskTxn & Text \\
\hline TaskAction & Text \\
\hline Taskfields & Text \\
\hline TaskKey & Text \\
\hline TaskTime & Text \\
\hline
\end{tabular}

\begin{tabular}{|c|c|}
\hline \multicolumn{2}{|c|}{ E UserTable : Table } \\
\hline Field Name & Data Type \\
\hline BID & AutoNumber \\
\hline UserID & Text \\
\hline UserName & Text \\
\hline Password & Text \\
\hline Level & Number \\
\hline Profile & Text \\
\hline Status & Text \\
\hline Expiry & Date/Time \\
\hline
\end{tabular}

Gambar 17 Tabel TaskTable dan Tabel UserTable

\section{Implementasi Sistem}

Tahap ini menjelaskan alat yang dibutuhkan untuk perangkat keras dan lunak serta rencana implementasi. Implementasi dilakukan pada sebuah PC yang terhubung pada jaringan. Hal itu agar dapat mengirimkan laporan via email.

Kebutuhan Perangkat Keras: Pentium 4 CPU 2,80 GHz; Hard Disk 40 GB; Memori 0,99 GB of RAM.
Kebutuhan Minimum Perangkat Lunak: System Microsoft Windows XP Profesional Version 2002 SP 2; Microsoft Outlook 2003; PGP software; Commail software. 


\section{Rencana Implementasi}

Tabel 1 Tabel Rencana Implementasi

\begin{tabular}{|c|c|c|c|c|c|}
\hline No. & Kegiatan & Minggu 1 & Minggu 2 & Minggu 3 & Minggu 4 \\
\hline 1. & Penyediaan perangkat keras & & & & \\
\hline 2. & $\begin{array}{l}\text { Instalasi operating system dan perangkat } \\
\text { lunak yang digunakan seperti microsoft } \\
\text { office }\end{array}$ & & & & \\
\hline 3 & $\begin{array}{l}\text { Instalasi aplikasi automail, copy } \\
\text { PGP.exe, dan copy Commail.exe }\end{array}$ & & & & \\
\hline 4 & $\begin{array}{l}\text { Training penggunaaan aplikasi automail } \\
\text { bagi user }\end{array}$ & & & & \\
\hline 5 & $\begin{array}{l}\text { Training bagaimana caranya deskripsi } \\
\text { laporan yang telah terenkripsi untuk } \\
\text { setiap company partner }\end{array}$ & & & & \\
\hline
\end{tabular}

\section{Level Pengguna Aplikasi Automail}

Berikut adalah layar login aplikasi automail dan layar tampilan seluruh menu. Ada tiga level pengguna aplikasi automail. Pertama, Admin berfungsi untuk membuat user baru yang memiliki level supervisor dan operator. Menu yang dapat diakses oleh admin adalah seluruh menu yang terdapat pada aplikasi automail. Kedua, supervisor berfungsi untuk meng-override jika terjadi pengiriman ulang laporan yang gagal dikirim, override bila terjadi perubahan pada Address book, dan menghapus laporan yang telah terkirim. Menu yang yang dapat diakses oleh supervisor adalah Properties, Purge File, User Activities, dan Help Topic. ketiga, Operator berfungsi untuk melakukan pengiriman laporan. Menu yang dapat diakses oleh operator adalah Address book, menu Run (Report Verification dan Send Email), Menu View(Address Book dan Verification \& Send Result), Menu Print (Address Book dan Sent Email), dan Help Topic.

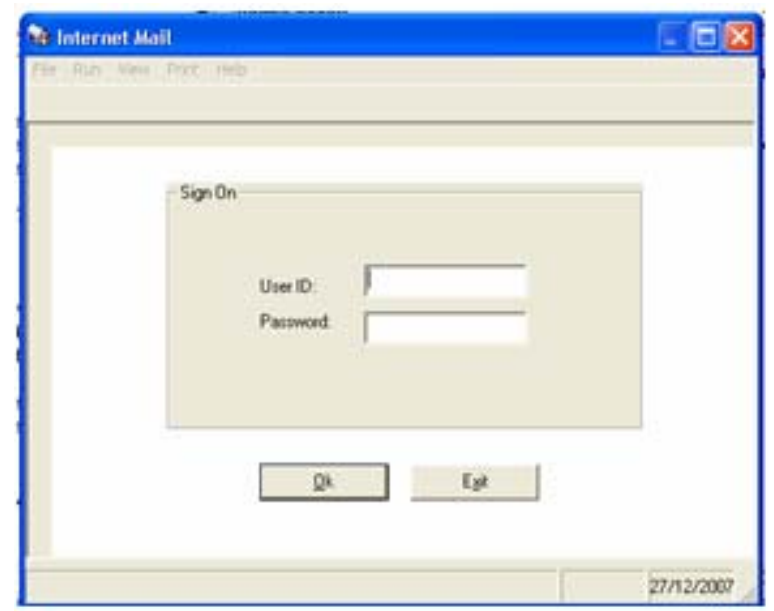

Gambar 18 Layar Login aplikasi Automail 


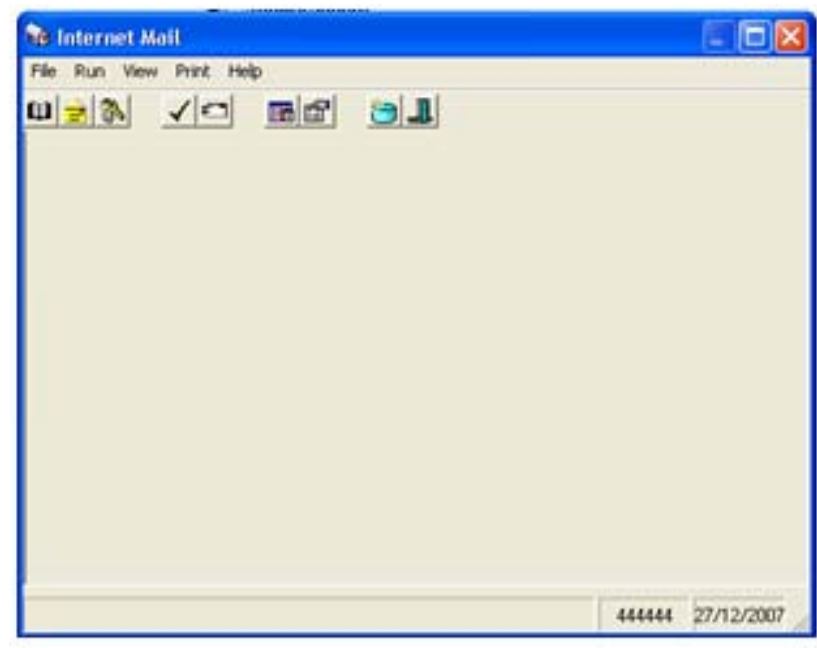

Gambar 19 Aplikasi Automail

Tahapan penggunaan aplikasi automail ini adalah Admin membuat user baru untuk supervisor dan operator; Supervisor akan men-setup nama subject, direktori PGP, dan direktori untuk aplikasi automail di menu Properties; Setelah itu, setiap harinya operator akan menjalankan Run-Report Verification untuk mengirimkan laporan transaksi. Lalu status berhasil atau tidaknya dapat dilihat di menu View-Verification \& Send Result; Jika akan mengirimkan ulang maka operator menjalankan Run-Send Email dengan override dari supervisor; Jika proses pengiriman telah selesai supervisor akan menghapus seluruh laporan-laporan melalui menu Purge File; Untuk keperluan audit, maka supervisor akan mencetak user activities.

\section{Evaluasi Perubahan Sistem}

Evaluasi perubahan sistem digunakan untuk mengetahui secara rinci kelebihan sistem baru yang dihasilkan, apakah benar-benar bermanfaat mengurangi fraud yang terjadi dan lubang kelemahan yang ada pada pengiriman laporan transaksi, seperti proses verifikasi, pemecahan, dan enkripsi pada sistem lama dapat ditutupi oleh sistem baru. Dapat dilihat secara lebih mendetail lagi pada tabel perbandingan antara sistem lama dan baru berikut. 
Tabel 2 Tabel Perbandingan Antara Sistem Lama dan Sistem Baru

\begin{tabular}{|c|c|c|}
\hline No. & Sistem lama & Sistem baru \\
\hline 1. & $\begin{array}{l}\text { Laporan transaksi dibuka dengan } \\
\text { bantuan program editor seperti } \\
\text { textpad, ultraedit, notepad, dan } \\
\text { program editor lainnya. }\end{array}$ & Dilakukan oleh aplikasi automail. \\
\hline 2 . & $\begin{array}{l}\text { Laporan transaksi dipilah-pilah } \\
\text { dengan cara meng-copy dan paste } \\
\text { pada file text baru sesuai dengan } \\
\text { kode company partner }\end{array}$ & Dilakukan oleh aplikasi automail. \\
\hline 3. & $\begin{array}{l}\text { Mengenkripsi file text yang baru } \\
\text { tersebut dengan program PGP dan } \\
\text { Cornmail }\end{array}$ & Dilakukan oleh aplikasi automail dan PGP dan Commail. \\
\hline 4. & $\begin{array}{l}\text { Mengirirnkan file te } x \text { pada company } \\
\text { partner dengan program microsoft } \\
\text { outlook. }\end{array}$ & Dilakukan oleh aplikasi automail dan microsoft outlook. \\
\hline
\end{tabular}

PENUTUP

Simpulan yang dapat diambil dari analisis dan perancangan aplikasi automail ini adalah fasilitas yang terdapat pada aplikasi automail ini adalah registrasi data company partner, verifikasi data, pengiriman email dengan enkripsi, pengiriman ulang laporan yang gagal dan bermasalah, override supervisor, dan laporan aktivitas yang terjadi. Dengan adanya aplikasi automail ini maka fraud yang terjadi dapat dikurangi bahkan dihilangkan.

Adapun saran untuk pengembangan analisis dan perancangan aplikasi automail ini adalah perancangan ini dapat dikembangkan lagi sesuai penambahan proses bisnis dan perlu diperhatikan dan ditingkatkan, khususnya aspek keamanan dalam pengiriman laporan yang bersifat finansial.

\section{DAFTAR PUSTAKA}

Connolly, Thomas M. 2002. Database System: A Practical Approach to Design, Implementation and Management. Pearson Education Limited.

Mathiassen, Lars and Andreas Munk-Madsen. 2000. Object Oriented Analysis and Design. Denmark: Marko Publishing ApS, Aalborg.

O’Brien, James A. 2006. Pengantar Sistem Informasi. McGraw-Hill

Shneiderman, Ben. 1998. Designing the User Interface: Strategies for Effective Human Computer Interconnection. Third Edition. Addison Wesley Longman, Inc, Massacuhsetts.

Sarita, Singh. "Stream Chipper Design - Based on The Clause SatisfiabilityProblem," Procedings Seminar Nasional Sistem \& Informasi 2007, STIKKOM Bali. 